\title{
Rewilding in layered landscapes as a challenge to place identity
}

\author{
Martin Drenthen
}

\begin{abstract}
Rewilding is an increasingly popular strategy in landscape management, yet it is also controversial, especially when applied in culturally 'layered' landscapes. In this paper I examine what is morally at stake in debates between proponents of rewilding and those that see traditional cultural landscapes as worthy of protection. I will argue that rewilding should not only be understood as a conservation practice, but that we also need to understand the hermeneutic aspect of rewilding. Rewilding implies a radical non-anthropocentric normative reinterpretation of landscape and human history that calls for a critical re-examination of the cultural identities that are based on that history.
\end{abstract}

\section{KEYWORDS}

rewilding, place, landscape heritage, environmental ethics, environmental hermeneutics

\section{Introduction}

In her paper 'Rethinking rewilding' (Jørgensen 2015), environmental historian Dolly Jørgensen discusses the "complex history and a host of meanings" of the term 'rewilding'. She shows that whereas at first the term had a strict meaning in a scientific context, it later moved outside the realm of science and was adopted by environmental activists as a fundamentally asocial and ahistorical 'plastic' word without specific content. According to Jørgensen, 'taken as a whole, rewilding discourse seeks to erase human history and 
involvement in the land and flora and fauna', implying a 'split between nature and culture [that] may prove unproductive and even harmful' (Jørgensen 2015, 482). In a response, Prior \& Ward (2016) claim that actual cases of rewilding do in fact 'acknowledge the implicit entanglement of non-humans and humans in conservation endeavours', but 'celebrate nonhuman autonomy in rewilding as fundamental to the creation of experimental, forward looking conservation cultures' (Ward \& Prior 2016, 134). Rewilding therefore does not necessarily collapse into anti-human wilderness management.

In this paper, I examine the tension between the idea of rewilding on the one hand, and the historical and social recognition of the significance of human involvement in landscapes on the other hand. I agree with Prior and Ward that actual rewilding projects often acknowledge the entanglement of nature and culture, but I also believe that Jørgensen is right about the fundamentally asocial and ahistorical nature of much rewilding discourse. In this paper, I argue that there does not have to be a contradiction between the two. I argue that rewilding is not just a conservation practice and a discourse, but also implies a specific nonanthropocentric perspective on landscapes and the role of humans in nature, and that we will only be able to understand what is at stake morally in debates on rewilding in cultural landscapes by making explicit this interpretational dimension of the rewilding debate.

I will first briefly discuss the general nature of conflicts about rewilding in cultural landscapes, and argue that in order to understand what the debate is about we need to address the narrative aspects of the debate. Next I will argue that rewilding and landscape heritage narratives are based on specific interpretations of the landscape. I will then show, using philosophical hermeneutics as inspiration, that these different readings of the landscape text are in inextricably linked to notions of moral identity. Finally, I show that this implies that the ahistorical nature of rewilding discourse should primarily be thought of in terms of a moral 
criticism of the way that dominant anthropocentric perspective fundamentally distorts our understanding of humans' role in natural history.

\section{New nature in old landscapes}

But let me first say a few words about the term rewilding. The term rewilding is used by scientists, conservationists or environmental activists, and accordingly has many different meanings (Jørgensen 2015), but all of these can be seen as part of one big cluster of meanings (Gammon, forthcoming). It is a relatively recent term, but the kinds of projects that today are labelled as rewilding have a longer history. In the Netherlands in particular, rewilding has a history of several decades, although the most commonly used term for projects that today would be labelled 'rewilding' is 'nature development' ('natuurontwikkeling') or 'new nature' (Bulker et al. 2016). Many early 'nature development' projects were part of the so-called Room for the River program, which aimed to alleviate flood risks by creating new wetlands in former agricultural land in river forelands and 'liberate' rivers from their straightjacket of dikes and levees (Drenthen 2009a). 'Nature development' has often been translated as 'ecological restoration' by many scholars, myself included, but since most if not all of these projects do not so much aim to restore an original state, but rather 'bring back' natural processes and thus 'highlight and foreground non-human autonomy' (Ward \& Prior 2016), 'rewilding' is a much better term for these projects. It is important to note that 'new nature' that is thus created is not presented as 'pristine' or 'original', but still as 'genuine nature' (or even as "new wilderness"1), because it results from the workings of autonomous natural processes.

\footnotetext{
${ }^{1}$ The New Wilderness ['De Nieuwe Wildernis'] was the title of a successful feature documentary about the Oostvaardersplassen nature reserve near Amsterdam that won the 'Gouden Kalf' award for 'Best Dutch Movie of the Year' in 2014.
} 
Most rewilding projects focus on restoring natural processes and are characterized by an 'experimental' approach (Lorimer \& Driessen, 2014) and an open-ended orientation to the future (Hughes et al., 2011, Carver 2012). Although 'some rewilding projects establish specific historic baselines for ecosystem functionality (e.g., Pleistocene, pre-agriculture), rewilding does not aim to recreate landscapes in some idealized past form' (Gammon, forthcoming, also Hall 2010). It is frequently assumed, though, that the autonomous forces of nature, if set free, often will eventually reproduce landscapes that resemble those that existed before humans appeared. Similarly, even though rewilding projects hardly ever have the explicit goal to 'erase human history and human involvement in the land' (Jørgensen 2015, 482), it is also true that they do often start with the removal of human artefacts and structures - dykes, levees, wooded banks, canals and other cultural artefacts - that are thought to impede ecological processes. For that reason, when rewilding projects take place in old cultural landscapes, they often encounter stark opposition.

Many traditional European cultural or half-natural landscapes are under threat, because they depend on land use practices that are rapidly disappearing due to economic and demographic developments such as urbanization, growth of infrastructure, changes in land use such as intensification of agriculture, but also land abandonment in places with poor soils and low yields. As a result, old land use patterns that support cultural identities are eroding. These changes also affect the particular assemblage of species that depend on these specific and contingent historic human-nature relationships. Sometimes, locally extinct species or nonnative species can take advantage of changing environmental conditions and recolonize abandoned areas (for instance large predators, Chapron et al. 2014), but their appearance only leads to a further transformation of the landscape.

Old cultural landscapes are valued for a variety of reasons. Some argue for the protection of old cultural landscape as part of a cultural heritage. According to the European Landscape 
Convention, the European landscape landscape is 'a basic component of the European natural and cultural heritage' that is 'contributing to human well-being and consolidation of the European identity' and should therefore be protected (European Landscape Convention, 2000). Inhabitants value the old traditional landscape because it supports their traditional way of life and provides them with a livelihood; studies indicate that a rapid change of landscapes can lead to a sense of placelessness and disorientation (Buijs 2009, Tonnaer 2014). Many others value these landscapes because of their beauty (McMorran et al. 2006), archaeologists and historians because they contain an old cultural-historical archive, writers and cultural geographers because these cultural landscapes reflect a diversity of unique human-landscape relationships worth protecting. There even exist grant programs that put landscape heritage conservation at the heart of rural regeneration, such as UK Heritage Lottery Fund for socalled Landscape Partnerships ${ }^{2}$, and try to get more people involved in understanding and looking after these landscapes for the long term by conserving habitats at landscape-scale, promoting joined-up management, and reviving long-lost skills.

Traditional nature conservation groups, on the other hand, value these old landscapes for other reasons: primarily for their natural value and the way they have come to harbour a rich biodiversity. Whereas nature conservation and preservation efforts in North America traditionally aimed at the protection (and restoration) of 'wilderness' - supposedly undisturbed, pristine places - in the Old World context of Europe, conservationists often focused on preserving the anthropogenic, mainly agricultural semi-natural and cultural landscapes that had developed over thousands of years of relatively consistent land use (Hall 2005, Drenthen \& Keulartz 2014). Many 'Old World' landscapes are, if you want, the result of a long history of human 'disturbances' or, to put it more positively, a history in which

2 http://www.hlf.org.uk/looking-funding/our-grant-programmes/landscape-partnerships. Accessed September 25, 2017. 
human culture and nonhuman natural elements coevolved in a dialectic process of mutual involvement. The Dutch biologist Victor Westhoff introduced the concept of 'semi-natural' to characterize these small-scale pre-industrial agricultural landscapes (Westhoff 1970), and pointed out their exceptional ecological value. He argued that in order to maintain them, they demand continued intervention: 'if nature was simply left to run its course, then heaths and mashes, for instance, would degenerate irrevocably and lose their biological diversity' (Keulartz 1998: 160, also see Deliège 2016).

But while both 'heritagists' and traditional conservationists regret the changes to the cultural landscape and want to conserve what is left of them, today the appreciation of these old cultural landscapes is shifting, for a large part due to the rise of the idea of rewilding. Some rewilding advocates argue that instead of trying against better judgment to conserve the old and obsolete cultural landscapes with their species composition, we should accept the inevitable, seize the opportunity for a change for the good, and focus our attention on the creation of new, wild landscapes that will be able to stand on their own feet. Rewilding aims to 'revitalize' the old landscapes by reintroducing missing species and missing natural processes. In doing so, however, rewilding is not just a response to inevitable landscape change, it can also become a driver of change on its own. For that reason, opponents of rewilding see rewilding projects as just another blow to the old landscape they care about. But rewilding initiatives also appear to have fairly wide support (Schepers \& Jepson 2016). A study in Switzerland found that roughly $50 \%$ of the general public supports rewilding (Bauer et al. 2009). A study in the Netherlands (Van den Berg \& Koole 2006) shows that wild, unmanaged nature is valued mostly by urbanites, and much less so by inhabitants of rural areas, especially those with an agricultural background (also see Howley 2011). Farmers and local inhabitants tend to appreciate the traditional agricultural practices as the basis for their traditional way of life; tourist, artists, historians and cultural geographers see it as the basis of 
an interesting and beautiful small scale cultural heritage landscapes, while many traditional European nature conservationists tend to see traditional agricultural practices as the basis of the 'half natural' ecosystems that harbour European species diversity.

Those in favour of rewilding, however, typically have a far more negative view of the impact of agriculture on the landscape. In his book Feral (Monbiot 2013), rewilding advocate George Monbiot criticizes the conservation of old British cultural landscapes that typically depend on the practice of sheep farming. Monbiot argues that 'sheep farming in this country is a slow-burning ecological disaster, which has done more damage to the living systems of this country than either climate change or industrial pollution' (Monbiot 2013, 158). When in July 2017 the UNESCO granted the Lake District the status of World Heritage Site, Monbiot called the decision a 'betrayal of the natural world' (Monbiot 2017).

Dutch rewilding advocate Frans Vera even argues that the very aim of farming is and has always been the reduction of biodiversity:

'Agriculture has caused the major problems with biodiversity. Agriculture means selection. Across Europe we have dismantled the natural ecosystems. Farmers only took out what they needed. Out of the seven species of native wild ungulates that lived here, they selected three: pig, cattle and horses, which were domesticated and bred. The rest were killed off. The absurd thing is that the meagre remnants of that process are now labelled as nature and the very cause of the suffering is now seen as the most important factor that produces nature. ${ }^{3}$

Influential rewilding advocates such as Vera and Monbiot argue that the old small-scale (agri)cultural landscapes are currently disappearing because of the same reasons that produced them in the first place. They argue that the delicate interplay of humans and nonhumans may have initially produced biodiverse and culturally diverse traditional landscapes, but only

\footnotetext{
${ }^{3}$ Cited in Van Lieshout \& Jansen 2008 [my translation, MD].
} 
because of the limited possibilities farmers had to control nature. Today modern farmers finally accomplished what their ancestors tried to but could not: to shift the balance from a situation of co-creation by humans and nonhumans to a situation of human control, where everything without apparent use to humans is discarded.

But just as the opponents, proponents of rewilding are also motivated by reasons having to do with nature and with culture. Monbiot argues that wildness as an element that has been lacking for too long in our modern societies (Monbiot 2013, 77), and that leaving room again for spontaneous natural processes and allowing for the creation of self-willed land, will lead to a richer world. One might regret- for cultural or ecological reasons - the disappearance of elements of the traditional small-scale cultural landscapes, but ultimately humans need to stop dominating and controlling nature and allow for wildness to resurface. To quote another British rewilding advocate, Steve Carver: 'succession and the associated changes in ecosystem complexes is, and ought to be, the default state of natural, self-willed ecosystems. Change happens. Get over it!' (Carver 2014, 8).

\section{A pragmatic resolution?}

One way to frame the conflicts between these perspectives is by saying that rewilders and heritage protectionists typically value different landscapes features. Both groups appreciate different 'items' on their list of valuable features in the landscape. ${ }^{4}$ Rewilders typically want to protect those 'natural values' that contribute to biodiversity, ecological integrity, and wildness, whereas defenders of cultural heritage landscapes typically value those items in layered cultural landscapes that meaningfully reflect human history, and contribute to a sense

\footnotetext{
${ }^{4}$ O'Neill, Holland and Light (2008) have characterized this approach towards environmental values, which according to them has dominated discourse on environmental values in the field of environmental ethics, as 'the itemizing approach'.
} 
of place, to historic authenticity and continuity, and to regional identity. Framed like this, there is no prima facie reason why these different values in the landscape could not be conserved at the same time; it might in fact be relatively straightforward once we understand that the features valued by both groups often exist in different places. The traditional conservation strategy of trying to continue old land practices to preserve and reproduce the intricate network of cultural and natural relations will be most appropriate in those places where traditional human land use practices and species that depend on them still exist. Rewilding, on the other hand, might fit best in those places where this historic fabric has disappeared to a large degree. In those places where traditional cultural and natural features already have been disrupted beyond repair, rewilding might be relatively uncontroversial.

Indeed, there is much to be said for such a pragmatic reconciliation. However, in reality, the conflict between these two approaches to landscape surfaces over and over again, for instance when rewilders propose to introduce missing species such as beaver or wolf in places where these animals have been wiped out long ago, or when farmers ask for subsidies to help conserve agricultural land use practices that have become economically unsustainable in light of the demands of current global food market. On those occasions conflicts easily escalate because the different parties are personally deeply involved. Some feel that their whole existence is under threat by rewilding. Sheep farmer James Rebanks writes: 'I love this place; for me it is the beginning and the end of everything, and everywhere else feels like nowhere' (Rebanks 2015, 17). His colleague Morris-Jones holds that '[ i]f you eradicate the evidence of our presence on the land, if you undermine the core economies that support the Welshspeaking population in the language's heartland, you write us out of the story. We've got nothing else' (cited in Monbiot 2013, 176-177). Rewilding proponents, on the other hand, also claim that rewilding is an issue of deep personal concern to them: it is about whether or not we can truly 'feel alive' (Carver 2014, 12, Monbiot 2013, 255) and that we should be 
'rewilding our hearts' (Beckoff 2014). Apparently there is much more at stake than merely a difference in landscape preference.

I believe that a hasty pragmatic reconciliation of both perspectives might blind us to the relevant normative differences between perspectives on landscapes, and can obscure what is at stake in the debate between heritage and rewilding. The competing normative perspectives do not just differ on which 'landscapes features' are considered valuable, but also involve different normative narratives about ourselves and our place within these landscapes.

\section{A narrative approach to the conflict}

O’Neill, Holland and Light (2008) argue that conflicts that arise from the pull of competing and often incommensurable environmental values can only be addressed properly if more attention is paid to the role of time and narrative in the human relations with environments. The starting point of a narrative approach towards environmental values is that:

'An individual's identity, their sense of who they are, is partly constituted by their sense of belonging to particular places. Particular places, whether "natural" woodlands, streams and ponds, or "urban" city streets, parks and quarries, matter to individuals because they embody the history of their lives and those of the communities to which they belong. Their disappearance involves a sense of loss of something integral to their lives.' (O’Neill, Holland and Light 2008, 39)

Moreover, the narrative approach claims that 'people make sense of our lives by placing them in a larger narrative context, of what happens before us and what comes after. Environments matter because they embody that larger context' (idem, 198). In other words, the narrative approach holds that environments provide us with a horizon, or a context from which we can come to understand ourselves. 
However, if we focus on the narrative dimension of the conflict between rewilding and cultural heritage landscape protection, we see that different parties start from different interpretations of the environment as a horizon for self understanding. The conflict is not merely about which landscape features are worth protecting, it also is a clash between different ways to frame the issue: a clash between different horizons from which we contextualize our current situation.

From the perspective of those who oppose rewilding and stress the value of the landscape heritage, we today are the heirs in a long line of inhabitants that transformed the landscape and made it habitable to humans. In other words, for heritage landscape protectionists, the long history of appropriation of and human involvement in the landscape is what has created meaningful places. From that perspective, a removal of human traces from the landscape would inevitably lead to meaningless landscapes. Welsh shepherd and translator Daffyd Morris-Jones opposes the idea of rewilding because 'with blanket rewilding you lose your unwritten history, your sense of self and your sense of place. It's like book-burning.' (cited in Monbiot 2013, 176-177). To him, the old cultural landscape is like a meaningful text one can inhabit, and rewilding is destroying its legibility. All features in the landscape tell a story about the land and the community who has live on it (Tokarski \& Gammon 2016) and as such provides a context from which his own life gains a specific meaning.

In contrast, rewilders typically start from the temporal context of natural history, in which 'natural environments have histories that stretch out before humans emerged and they have a future that will continue beyond the disappearance of the human species.' (O'Neill, Holland and Light 2008, 162.) Such a time horizon is thoroughly non-anthropocentric, because it stretches way past the confines of human history into deep time, places the story of human involvement in the land within a broader context and thus puts that involvement in 
perspective: 'Unintentional natural processes provide part of the context in which intentional human activities take place and through which we understand their value'( idem, 198).

Rewilders believe that we should abandon these outdated agricultural practices, even if that means that some local inhabitants will no longer be able to continue their ancestors' way of life (Monbiot 2013, 167 -185).They worry that traditional strategies to conserve heritage landscapes will reinforce the disruptive anthropocentrism of traditional land practices and will eventually go at the expense of non-human nature. Through their temporal focus on the deep time perspective of natural history, rewilders can take distance from the human history of cultivation of the land. Despite their claim that they do not want to remove humans from nature but rather try finding a new way to engage with it (Monbiot 2013, 11), this move of putting in perspective human history and human involvement in nature appears to be a key element of the rewilding perspective.

What this concise narrative analysis reveals is that the conflict does not just revolve around which landscape features have value, or even about the value and meaning of humanized landscape. At the core of the conflict lies the question of from which horizon or context the text of the landscape (and human involvement in it) should be interpreted - and that question is deeply linked to how we think about ourselves and our place in the world. If we want to understand what is at stake in the debate about rewilding, we need to see how a concern for the landscape is always also about us and what it means to be human. In order to better understand this relation, it can be helpful to examine a bit closer Morris-Jones' idea that landscapes are as texts, and rewilding is like book burning.

\section{Landscapes as texts in need of interpretation}


The landscape text metaphor has been popular among geographers and geologists, environmental scientists, historians, archaeologists, environmental educators, and nature writers. In most of these works, it is implicitly assumed that our relation with legible landscapes is comparable to the way we read informative texts. Landscapes are seen as objective structures containing signs that refer to each other, as objects closed in upon themselves. ${ }^{5}$ On this account, readers are merely the neutral observers: everyone who knows how to read will understand the signs in the same way; thus the subjectivity of the reader does not really play a role in this type of understanding.

Some landscape researchers have tried to go beyond the notion of landscapes as passive, static objects of interpretation. In recent years, Dutch landscape researchers from archaeology and historic geography have developed the concept of 'landscape biography' in which landscapes are seen as elements in a dynamic relationship between humans and their environments (Kolen \& Renes, 2015). The landscape biographical approach examines the role played by the landscape in the identity construction of local communities, not just in the past but also in the present. It focuses on the multi-layered nature of landscapes, seeks to include long-term dimensions of transformations in landscapes as well as recent developments, and it stresses the dynamic nature of our understandings of the landscape text. The landscape is seen as a layered palimpsest that is constantly being written and rewritten:

'All landscape transformations necessarily involve a reordering, reuse and representation of the past which gives landscape development an almost non-linear character.' (Roymans et al. 2009, 339.)

Moreover, the landscape biography approach acknowledges that human identities are formed partly on the basis of place narratives, concepts and representations of place and space, and individual and collective memories and experiences of landscape. It acknowledges that

\footnotetext{
${ }^{5}$ For a more elaborate analysis of this approach, see Drenthen 2011.
} 
humans interpret and reinterpret the landscape in an ongoing process in which landscapes help to form people's identities and in which the interpretations of landscape in turn play a formative role in social processes producing landscape change.

'Places and landscapes play an active role in the biographies and genealogies of people, binding persons and generations together, while at the same time creating their own life histories at different time scales through successive social contexts.' (idem)

The landscape biographical approach shows how both landscapes and human identities are transformed in close interaction with each other, recognizing the objectivity of the landscapes that form our identities, while also acknowledging that our self-understanding influences the way we understand and change landscapes. Therefore, it can help us understand how different reading of cultural landscapes can lead to different notions of environmental identity.

However, for understanding what is at stake morally in the debate between different readings of the landscape, we need another conception of what it means to read a text. We can take inspiration from philosophical hermeneutics, which does not start with the experience of reading an informative text, but rather focuses on the way we understand the meaning of literary texts such as poems and novels.

\section{A hermeneutic perspective on reading landscapes}

According to Paul Ricoeur, humans are truly narrative beings, who know themselves through the stories that are being told: it is in our identification with the stories we tell about our lives to ourselves and to others, that our (narrative) identity is established (Ricoeur 1992). It is in this context that a text can present itself to a reader as somehow meaningful and therefore worthwhile reading. While reading a novel, a reader can only find meaning in the text if he or she is actively involved in the act of reading. One may start with an 'objective', structural 
analysis of how the text is internally structured, but in order to understand what that text has to say to us, and why that might matter - the meaning of a text - one cannot stop there. For that, one needs to allow the text 'to open up a world', and then step into that world. We can only understand what a novel has to say to us if we assume that the world of the text is somehow also our world; that it can give us experiences we would otherwise never have, and as such help us get a new perspective on ourselves and our world. If the reader answers to the 'invitation of the text', then the 'refiguration of the world by the text' can bring about an active reorganization of the reader's being-in-the-world (Ricoeur 1981). Thus, one's narrative identity is determined by texts that disclose horizons of new worlds. Through the act of reading, a text can change both the reader's world and their identity.

This perspective can easily be expanded to include the act of reading landscapes as formative for our personal place-based identity. Reading the land as text requires an active engagement with the meaning of a place that beckons to be understood; articulating its meaning requires an act of interpretation, in which we must both actively appropriate the meaning by investing ourselves in the landscape, and at the same time let the text change our world. Understanding what a landscape means requires reconstructing its story but also more than that: we need to somehow acknowledge the storylines inscribed in the landscape and decide how these stories are also about us. Stories about the meaning of a place and what it means to be in that place reflect and support our identity but can also transform it. Ricoeur argues that we do not have an immediate access to who we are (e.g. through introspection), but rather that our (narrative) identity is established in our identification with the stories about us. Similarly, through the act of reading the landscape, it - too - can become intertwined with my own life story; it can tell me something about myself that I did not know before. Thus, a landscape can become an ethos - a true dwelling place that defines who I am and what my life is about. Just like literary texts do not merely represent the world, but present a world that the 
reader can inhabit, so landscapes are not just the objects of our concern that merely reflect who we are and what we did and what we have valued, but they also work upon us, and help us to gain a new perspective on ourselves.

Moreover, as Gadamer has pointed out, our interpretations never start from scratch, but will always already be influenced by and embedded in a history of interpretations that precedes us ('effective history', Gadamer 2006). Similarly, one may argue that landscapes are always already infused with meanings, and have always already presented themselves to us as somehow meaningful and worthwhile exploring, embedded in a larger whole of meanings and interpretations that are already in play in how we see the world and ourselves. We do not choose to interpret landscapes in a particular way, on the contrary, certain meanings present themselves to us before we even realize it. The act of reading landscapes is a normative practice that makes explicit how we are always already 'emplaced' (Clingerman 2004).

Any serious and critical landscape reading requires that we acknowledge this intertwinement: we must learn to understand how places have always already contributed to who we are, acknowledge the existing connections and dialectics between us as readers and landscapes worth reading. We should learn to understand ourselves through the landscape that we find ourselves in, and then move on to produce more adequate interpretations of the meaning of the land to enable more adequate practices. Our narratives of the landscape themselves are already a response to the landscape text that we are always already involved in - but a confrontation with alternative readings might trigger us to rethinking of how we see ourselves.

\section{Reading a palimpsest landscape}


How can this detour help our analysis of the conflict on rewilding? From a hermeneutic perspective, rewilding and heritage landscape protection both appear as interpretative practices that are built on particular but partial readings of the palimpsest landscape. Both readings imply a particular understanding of the moral significance of a landscape and of what it means to exist in these places, but typically do so from their own temporal horizon and by focusing on only parts of the palimpsest.

Each genuine interpretation of a landscape only comes into existence by an active interpretative act of us as readers and interpreters, but that does not mean that these are freely invented. The particular meaning that one discovers is not an 'invention' of the reader, but the way the text of the landscape resonates with earlier traditional interpretations that have in part formed us into who we are, with our particular moral sensitivities, our ideas about our place in human history and about how an appropriate relation to the landscape should look like, etcetera. Each of these attempts to understand and appropriate the meaning of the landscape text will always be context dependent. This does not make the story of what it means to live on this land any less real, but it does mean that it will be based on all the always already given stories and landscape interpretations 'out there.' It is through our identification with those stories, that our (narrative) identity is established. ${ }^{6}$ Such a story can be seen as a response to a meaning that is found in the world and is 'geared towards the preservation' of that meaning (Deliège 2016).

Since both heritage conservation and rewilding consist of partial interpretations, together they can contribute to a more comprehensive view on the meaning of layered landscapes. But there remains an obvious tension between them. Heritage protectionists typically relate to (relatively recent) historical textual layers; they seek to protect cultural landscape elements as

\footnotetext{
${ }^{6}$ This is not to deny that there also exist more shallow interpretations of landscape, that are introduced in the debate for political or ideological reasons. Often, such interpretations are not based on a reading of the landscape, but rather are imposed on the landscape text.
} 
shared reference points that tell a meaningful narrative about human place involvement and therefore support place identity and a place-based ethics. Seen from here, an old agricultural landscape may bring to mind long-gone worlds of traditional farming, where humans and land lived together in mutual dependence, a history that may not be unproblematic, but it is ours. Historically deeper layers are seen merely as the background on which human history has played out, the circumstances our ancestors had to live with, resources they could use and challenges they had to face. Thus, the heritage perspective has a fairly limited, human-centred account of 'what happens before us and what comes after'.

But rewilding provides an alternative reading. It starts with an alternative structural reading of the landscape text that focuses the attention on those features of the text that earlier interpretations failed to properly recognize yet need to be acknowledged. Frans Vera provides an interesting example of such a reinterpretation, when he criticizes traditional conservationists who believe we need old agricultural landscapes if we want to protect meadow birds: 'For many people, the cultural country is still the reference image. Because they know meadow birds as lapwing and godwit from agricultural lands, they think that you need agricultural landscapes to have such birds. Apparently it is difficult for them to realize that those species once had a natural biotope' (quoted in Blankestijn 1997, my translation [MD]).

By calling attention to suppressed ecological processes or forgotten landscape features, rewilders stress that the existing cultural landscape and its history could only exist because of those formative ecological processes which have been suppressed and overlooked in recent times. Such a perspective focuses on the ecological costs connected to the history of some cultural landscapes, and may render the human history of these landscapes as inherently problematic. 
We can learn from Ricoeur's hermeneutics that in a serious interpretation, a 'structuralist' reading of the text will be supplemented with a broader hermeneutic understanding in which the world of the text merges with the world of the reader. Only through narratives do landscape histories get intertwined with our life stories and narrative identities in a way that they provide an ethos - a normative context or frame of orientation that help us to orient ourselves and from which we know who we are and what being in our particular place is about. The new structural reading of rewilding supports and justifies a broader narrative understanding of the meaning of landscapes for us.

Just as recognizing the recent top-layers of the landscape text can urge one to appreciate the landscape as part of one's history and identity (or thus want to maintain or restore cultural patterns), the acknowledgement of the deeper and older layers challenges one to restore a sense of continuity with a deeper or older natural history that humans have changed in the past and that is often forgotten. Some rewilders use the concept of a 'base-line' (Vera 2010) to refer to such a broader context for our understanding.

It is easy to misinterpret the role of this notion of base line as a sign that rewilders seek to restore wilderness and 'erase human history and human involvement in the land' (Jørgensen 2015) and return the landscape to an earlier pre-disturbance state. Even when suggesting that the new wildernesses somehow reflect landscapes of the past, most rewilders readily admit that it is impossible to reverse history and turn back to an undisturbed past. Often, they do not even pretend to know how the land looked like before humans entered the stage, although there often exists an ambivalence at this point. Frans Vera, for instance, on the one hand often also argues that conservationists and ecologists should stop pretending that we know what nature is supposed to look like, and instead be patient just wait and see how nature develops on its own when given a chance (Blankestijn 1997). And yet, on the other hand, he is well known for his 'open canopy hypothesis' regarding the 'true natural conditions' of the 
European landscape (Vera 2010, 98), which would seem to legitimize the use of large herbivores in rewilding projects (Hall 2014). A similar ambivalence can be seen with other rewilders as well. I therefore suggest that these kinds of references to a base line are primarily meant to shift the perspective for a reinterpretation of the landscape. References to a baseline are like tokens that help support a re-interpretation of human history and landscape from a deep time horizon that allows us to see nature itself unfolding as it always has done before us and will continue to do after we're gone. And that thus helps restore the narrative continuity in deep time.

If my analysis is correct, then the moral core of the rewilding narrative lies in its ability to morally challenge us to reinterpret ourselves and our history of involvement in the landscape, by changing the interpretational horizon and situating ourselves within a wider ecological history.

\section{Living in a palimpsests landscape - history goes on}

From a hermeneutic perspective, the moral problem that rewilding conflicts in cultural landscapes confront us with, is that different interpretations of the palimpsest text can all make sense, even if they seem contradictory. At this point, again, one might argue that both perspectives can be combined. After all, both perspectives aim to restore a sense of historic continuity, albeit with a different past, they refer to different layers of the palimpsest. ${ }^{7}$ Many have argued that by taking a place-based inclusive approach that recognizes both the cultural and the natural history of a site, the stark opposition between nature and culture might also be

\footnotetext{
${ }^{7}$ For an analysis of a concrete example of a landscape management conflict involving different time horizons, see Drenthen \& Deliège 2014.
} 
overcome (e.g. Longstreth 2008, Gobster 2012, Tallis \& Lubchenco 2014, Hourdequin \& Havlick 2016). Rewilding Europe seems to take a similar approach to rewilding:

'Rewilding helps landscapes become wilder, whilst also providing opportunities for modern society to reconnect with such wilder places for the benefit of all life. ${ }^{8}$

In such an inclusive perspective, one can acknowledge both the recent history and the deeper history of a place. Whereas the deep time perspective of rewilding provides a wider context to understand human history and put it in perspective, references to the recent cultural history in turn provide a context that can help situate rewilding projects as social/cultural practice. The Dutch Ark Nature Foundation, one of the founding parties of Rewilding Europe, explicitly acknowledges the importance of the cultural history of a rewilded landscape, in their "working definition' of rewilding:

'New nature is a new phase in the development of a landscape. And just like a book, a new chapter can be read better, after the previous chapters are well understood. Therefore ARK tries as much as possible to keep visible the cultural history of a region. When possible, historical elements will become meaningful again in the present. 9

The first step towards a fruitful exchange of perspectives may be the realization that the layering process in the landscape that has produced the landscape palimpsest is still going on. Whatever our take on the meaning of a particular landscape, our attempts to restore a sense of historic continuity will always necessarily involve adding new layers to the palimpsest. One can explicitly refer to and seek to uncover deeper and older layers of a palimpsest, but any attempt to return to a previous state fails to recognize the fact that we are as historical beings

\footnotetext{
${ }^{8}$ http://www.rewildingeurope.com/about/what-is-rewilding. Accessed September 25, 2017.

${ }^{9}$ See the Dutch FAQ section of the Ark website (in Dutch, my translation [MD]). Available on http://www.ark.eu/over-ark/ark-organisatie/veel-gestelde-vragen-over-ark. Accessed September 25, 2017.
} 
part of an ongoing landscape biography ${ }^{10}$. History inevitably involves layering as an ongoing process - adding new layers as time progresses. At best, those new layers will be inspired by and meaningfully connected to older layers and will provide a basis for a new narrative turn that meaningfully connects the past to future, old layers of the landscape palimpsest to new ones.

Once we accept that we inevitably add new historic layers to a palimpsest landscape, it might be possible to find creative solutions that allow us to acknowledge the significance of all layers of the text, recognize wildness and heritage.

An nice example of such a solution is the brownfield conversion site in the German Landschaftspark Duisburg Nord, where landscape architect Peter Latz changed the syntax of a derelict industrial landscape by placing the existing elements in a different narrative framework (Weilacher 2008). Not all layers and signs even have to be conserved literally in order to continue their narrative significance. For example, certain land artworks can rescue the narrative significance of particular historical significant structures without preserving them literally, by translating or transposing old structures as narrative elements into new greener materials (trees, ditches) that are no longer dependent on unsustainable land practices, but still carry on the older place narratives that might otherwise get lost. A row of trees may echo a wall, a simple rope swing may keep the memory alive of a former school building on a rewilding site. Land art may also have a more critical role in a re-examining of existing land narratives by thematizing more troubling elements of a site's history (Drenthen 2015).

Conceived like this, rewilding is not about rejecting culture, but is about the continuation of the landscape biography and creation of new heritage landscapes. Conceived like this, 'rewilding' provides a critical perspective on all-too-human history, while also

\footnotetext{
${ }^{10}$ A similar same problem would occur if we were to freeze the landscape a certain historic state even if the landscape itself does not literally change, its meaning inevitably will.
} 
acknowledging that any rewilding project will inevitably be part of an ongoing cultural history of involvement with the landscape. As I have already indicated, at least some rewilders seem to be willing to conceive what they do in those terms (Barraud \& Périgord 2013).

But doesn't this necessarily imply a collapse of the rewilding idea into nothing more than just another human land management strategy, just another addition to the landscape palimpsest that merely reflects whatever our contemporary sensitivities happens to value? Because of their pragmatism, Steve Carver calls the Rewilding Europe approach 'rewilding-lite'(Carver 2014). Isn't there something more radical at stake in our attempt to allow for wildness to resurface again?

\section{Rewilding as a cultural critique}

Up to this point I assumed that rewilding can be properly understood in terms of an attempt to restore the narrative continuity with the underlying legible landscape. I presented rewilding as the effort to put the human history of controlling nature in perspective and make room for more natural autonomy. But my interpretation of rewilding was firmly based on the assumption that rewilding is a thoroughly human, reflexive endeavour 'geared at preserving meaning' (Deliège 2016) of the landscape palimpsest.

But rewilding is not an isolated phenomenon, it is part of a broader cultural fascination in the contemporary world with 'wildness', 'wild nature' and 'wilderness' as expressed in contemporary novels, movies, documentaries and the like (Drenthen 2009b). There is an element in this cultural fascination with wildness that cannot be easily reconciled with the 
notion of a layered legible landscape. The problem has to do with the very concept of wildness itself.

Wildness in nature is valued as something radically other beyond our grasp; it fascinates us, precisely because it does not suit our human all-too-human order. We seek those encounters with wild nature that resist our act of appropriation, and try to express the meaning of those encounters. This paradox in the meaning of wilderness can be seen clearly in the work of some nature writers. ${ }^{11}$ In his book The Wild Places, Robert Macfarlane describes his experience of climbing Ben Hope in Scotland. He encounters this wild place as a place that does not lend itself to human 'imputation meaning':

'The comfortless snow-shires, the frozen rocks: this place was not hostile to my presence, far from it. Just entirely, gradelessly indifferent. Up there, I felt no companionship with the land, no epiphany of relation... Here, there was no question of relation. This place refused any imputation of meaning.' (Macfarlane, 2007, 157.)

Apparently, the reason why this place is so overwhelming and overpowering, is that it radically questions all those meanings that we humans impute on the world. Edward Abbey writes in a similar vein about the experience of the wildness of the Utah desert:

'Under the desert sun, in that dogmatic clarity, the fables of theology and the myths of classical philosophy dissolve like mist. The air is clean, the rock cuts cruelly into flesh; shatter the rock and the odor of flint rises to your nostrils, bitter and sharp. Whirlwinds dance across the salt flats, a pillar of dust by day; the thornbush breaks into flame at night. What does it mean? It means nothing. It is as it is and has no need for meaning. The desert lies beneath and soars beyond any possible human qualification. Therefore, sublime.' (Abbey 1971, 244 , emphasis added.)

\footnotetext{
${ }^{11}$ Thanks to Simon P. James for pointing me to these passages in Macfarlane's and Abbey's work. Also see James 2013.
} 
What does it mean to say, as Abbey does here, that nature 'means nothing'? I suggest that both these passages show a typical aspect of our contemporary experience of wild nature in which we find ourselves fascinated by something that is already there, that precedes and exceeds our interpretations, that is more-than-human - and, in that sense, inhuman - and therefore struggle to articulate its meaning. That is to say: nature appeals to us, not because its moral meaning fits in a particular moral framework, but because of the otherness that breaches this moral framework. The paradox: what interests us in wild nature is that which cannot be appropriated and interpreted and yet, has to be interpreted and put in human language if we are to articulate and discuss its meaning. In that sense, wildness is not primarily a descriptive term referring to the unruliness of nature, but a critical border concept (Drenthen 2005) that we use to self-critically reflect on our human finitude. Some American anarcho-primitivist groups use of the term rewilding in such a radical 'anti-civilization' sense:

'The old Earth First! Slogan, "Nature Bites Back", forms the basis of a philosophy of rewilding, in the anti-civilization context. This is not necessarily an exaltation of the coming ecological disasters, but rather, an unmediated reaction to something that seems inevitable, and a stern warning to our decadent culture. ${ }^{12}$

Aspects of this radical idea can even be recognized in those rewilding-lite discourses, where rewilding areas are presented as new cultural landscapes, but explicitly as paradoxical ones, that remind us that nature precedes and exceeds our imagery of nature, where we can still meet the amoral and unruly, get in touch with something that is not of their making. Rewilding Europe director Wouter Helmer once coined the phrase 'insane oasis' to talk about these places of 'new nature' as places of freedom, where one can put in perspective the alltoo-human rational 'sanity' of our everyday moral conventions. ${ }^{13}$ In such a view, the new wild

\footnotetext{
${ }^{12}$ Green Anarchy and the Wildroots Collective 2004.

${ }^{13}$ Helmer 1996, also see Tonnaer 2014.
} 
places function as critical borders that remind us of the fact that there is something beyond society, something that is not of our own making, that should be recognized as a valuable part of our world. Of course, these places can never be anything but reminders of a limit - since even though they are meant to give room for the more-than-human, these places are still created by humans and express what they appreciate and value.

\section{Conclusion}

To conclude, rewilding is not just a practice of highlighting the autonomy of nonhuman nature, it also is a movement that stresses an alternative interpretation of the landscape palimpsest, situating the history human involvement with the landscape in a larger context, and using this context for a critique of an all-too-human anthropocentric outlook on life. But this critique does not lead us out of culture or history, rather it introduces that which lies beyond an all-too-human culture into the cultural arena of moral values. However, those who believe that rewilding promises a radical departure from the human history of attempting to 'humanize' the land, might be asking too much. Ultimately, there is no escaping from history: all rewilding landscapes are layered cultural landscapes.

\section{References}

Abbey, E. 1971. Desert Solitaire, New York: $1^{\text {st }}$ Ballantine Books edition.

Barraud, R. \& M. Périgord. 2013. 'Rewilding Europe: A Renewal of Natural Heritagemaking?' L'Espace géographique 42(3): 240-255. 
Bauer, N, A. Wallner, \& M. Hunziker. 2009. 'The change of European landscapes: humannature relationships, public attitudes towards rewilding, and the implications for landscape management in Switzerland'. Journal of Environmental Management 90(9): 2910-2920.

Bekoff. M. 2014. Rewilding Our Hearts: Building Pathways of Compassion and Coexistence. Novato: New World Library.

Blankesteijn, H. 1997. 'De mens moet leren verwerken dat natuur fluctueert'. $N R C, 25$ October 1997.

Buijs, A. E. 2009. 'Public support for river restoration. A mixed-method study into local residents' support for and framing of river management and ecological restoration in the Dutch floodplains'. Journal of Environmental Management 90(8): 2680-2689.

Bulkens, M., H. Muzaini, \& C. Minca. 2016. 'Dutch new nature: (re)landscaping the Millingerwaard'. Journal of Environmental Planning and Management 59(5): 808-825.

Carver, S. 2012. '(Re)creating Wilderness: Rewilding and habitat restoration'. In P. Howard, I. Thompson \& E. Waterton (eds.), The Routledge Companion to Landscape Studies, pp. 383-394. London: Routledge.

Carver, S. 2014. 'Making real space for nature: a continuum approach to UK conservation'. $\operatorname{ECOS~35(3/4):~4-14.~}$

Chapron, et al. 2014. 'Recovery of large carnivores in Europe's modern human-dominated landscapes'. Science 346, 1517-1519.

Clingerman, F. 2004. 'Beyond the Flowers and the Stones: "Emplacement" and the Modelling of Nature'. Philosophy in the Contemporary World 11: 17-24.

Council of Europe. 2000. European landscape Convention. Florence.

Deliège, G. 2016. 'Contact! Contact! Nature Preservation as the Preservation of Meaning'. Environmental Values 25(4): 409-425. 
Drenthen, M. 2005. 'Wildness as Critical Border Concept; Nietzsche and the Debate on Wilderness Restoration'. Environmental Values 14(3): 317-337.

Drenthen, M. 2009a. 'Ecological Restoration and Place Attachment; Emplacing nonplace?', Environmental Values 18(3): 285-312.

Drenthen, M. 2009b. 'Fatal Attraction; Wildness in Contemporary Film'. Environmental Ethics, 31(3): 297-315.

Drenthen, M. 2011. 'Reading Ourselves Through the Land: Landscape Hermeneutics and Ethics of Place'. In F. Clingerman \& M. Dixon (eds.), Placing Nature on the Borders of Religion, Philosophy, and Ethics, pp. 123-38. Farnham: Ashgate Publishing.

Drenthen, M. 2013. 'New nature narratives. Landscape Hermeneutics and Environmental Ethics'. In: F. Clingerman, M. Drenthen, B. Treanor \& D. Utsler (eds.). Interpreting Nature, pp. 225-41. New York: Fordham University Press.

Drenthen, M. \& J. Keulartz. 2014. 'Introduction'. In M. Drenthen \& J. Keulartz (eds): Old World and New World Perspectives in Environmental Philosophy, pp. 1-14. Cham: Springer.

Drenthen, M. 2015. 'Layered Landscapes, Conflicting Narratives and Environmental Art. Painful Memories, Embarrassing Histories of Place?' In: D. Havlick \& M. Hourdequin (eds.). Restoring Layered Landscapes, pp. 239-262. Oxford: Oxford University Press.

Drenthen, M. \& G. Deliège. 2014. 'Nature Restoration: Avoiding Technological Fixes, Dealing with Moral Conflicts'. Ethical Perspectives 21(1): 101-32.

Gadamer, H.-G. 2006. Truth and Method. London: Continuum.

Gammon, A. forthcoming. 'The many meanings of rewilding: An introduction and the case for a broad conceptualization'. Environmental Values.

Gobster, P. 2012. 'Alternative Approaches to Urban Natural Areas Restoration: Integrating Social and Ecological Goals'. In: J. Stanturf et al. (eds.), Forest Landscape Restoration: 
Integrating Natural and Social Sciences, pp. 155-176. World Forests 15. Dordrecht: Springer.

Green Anarchy/Wildroots Collective. 2004. Back to Basics, Volume Three: A Primer for a Balanced Existence Amid the Ruins of Civilization. (Green Anarchy \#16/Spring 2004). Archived on http://docslide.us/documents/green-anarchy-rewilding.html, accessed 2 July 2017)

Hall, M. 2005. Earth Repair: A Transatlantic History of Environmental Restoration, Charlottesville: University of Virginia Press.

Hall, M. (ed.). 2010. Restoration and History. The Search for a Usable Environmental Past. New York: Routledge.

Hall, M. 2014. 'Extracting Culture or Injecting Nature? Rewilding in Transatlantic Perspective'. In M. Drenthen \& J. Keulartz (eds): Old World and New World Perspectives in Environmental Philosophy, pp. 17-35. Cham: Springer.

Helmer, W. 1996. 'Waanzinnige oases.' In: A. Barendregt, M. Amesz \& J. van Middelaar (eds.), Natuurontwikkeling: zin of waanzin?, pp.81-90. Utrecht: Department of Environmental Studies Utrecht University.

Hourdequin, M. \& D. Havlick (eds.). 2016. Restoring Layered Landscapes. Oxford: Oxford University Press.

Howley, P. 2011. 'Landscape aesthetics: Assessing the general publics' preferences towards rural landscapes'. Ecological Economics 72: 161-169

Hughes, F., P. Stroh, W. Adams, K. Kirby, J. Mountford, S. Warrington. 2011. 'Monitoring and evaluating large-scale, 'open-ended' habitat creation projects: A journey rather than a destination'. Journal for Nature Conservation. 2011; 19(4): 245-53.

James, S. 2013. 'Finding - and Failing to Find - Meaning in Nature'. Environmental Values 22(5): 609-625. 
Jørgensen, D. 2015. 'Rethinking Rewilding’. Geoforum 65: 482-488.

Keulartz, J. 1998. Struggle for Nature. New York: Routledge.

Kolen, J. \& J. Renes (eds.). 2015. Landscape Biographies. Amsterdam: Amsterdam University Press.

Longstreth, R. (ed.). 2008. Cultural Landscapes: Balancing Nature and Heritage in Conservation Practice. Minneapolis; University of Minnesota Press.

Lorimer, J. \& C. Driessen. 2014. 'Wild Experiments at the Oostvaardersplassen. Rethinking Environmentalism in the Anthropocene'. Transactions of the Institute of British Geographers 39(2): 169-181.

Macfarlane, R. 2007. The wild places. London: Granta Books.

McMorran, R., M. F. Price \& A. McVittie. 2006. A Review of the Benefits and Opportunities Attributed to Scotland's Landscapes of Wild Character. Inverness: Scottish Natural Heritage.

Monbiot, G. 2013. Feral. Chicago: University of Chicago Press.

Monbiot, G. 2017. 'The Lake District's world heritage site status is a betrayal of the living world'. The Guardian, 11 July 2017.

O’Neill, J., A. Holland \& A. Light (eds.). 2008. Environmental Values. New York: Routledge.

Prior, J \& K. Ward. 2016. 'Rethinking Rewilding: a response to Jørgensen'. Geoforum 69: $132-135$.

Rebanks, J. 2015. The Shepherd's Life: A Tale of the Lake District. London: Penguin.

Ricoeur, P. 1981. Hermeneutics and the Human Sciences. Ed. and transl. by John B. Thompson. Cambridge: Cambridge University Press.

Ricoeur, P. 1992. Oneself as Another. Transl. by Kathleen Blamey. Chicago: University of Chicago Press. 
Roymans, N., F. Gerritsen, C. Van der Heijden , K. Bosma \& J. Kolen. 2009. 'Landscape Biography as Research Strategy: The Case of the South Netherlands Project'. Landscape Research 34(3): 337-359.

Schepers, F. \& P. Jepson. (2016). 'Rewilding in a European Context'. International Journal of Wilderness 22: 25-30.

Tallis, H. \& J. Lubchenco. 2014. 'Working together: A call for inclusive conservation'. Nature 515, 27-28 (06 November 2014) doi:10.1038/515027a

Tokarski, M. \& A. Gammon. 2016. 'Cultivating a Dialogue: Rewilding, Heritage Landscapes, and Belonging'. The Trumpeter 32(2): 146-154.

Tonnaer, A. 2014. 'Envisioning the Dutch Serengeti: An Exploration of Touristic Imaginings of the Wild in the Netherlands'. In N. Salazar \& N. Graburn (eds.), Tourism Imaginaries: Anthropological Approaches, pp. 242-259. New York: Berghahn Books.

Van den Berg, A., \& S. Koole. 2006. 'New wilderness in the Netherlands: An investigation of visual preferences for nature development landscapes'. Landscape and Urban Planning 78: $362-372$.

Van Lieshout, M. \& C. Jansen. 2008. 'Ecologische Hoofdstructuur in de verdrukking'. De Volkskrant, 8 July 2008.

Vera, F. 2010. 'The Shifting Baseline Syndrome in Restoration Ecology'. In M. Hall (ed.): Restoration and History, pp. 98-110. New York: Routledge.

Weilacher, U. 2008. Syntax of Landscape. The Landscape Architecture of Peter Latz and Partners. Basel: Birkhauser Verlag.

Westhoff, V. 1970. 'New criteria for nature reserves'. New Scientist 46:108-113. 